\title{
THE ORIGIN OF THE SEX-CELLS OF AMIA AND LEPIDOSTEUS
}

\author{
BENNET M. ALLEN
}

From the Department of Anatomy, University of Wisconsin

TWENTY-SEVEN FIGURES

\section{INTRODUCTION}

There has been an increasing amount of attention given in the last few years to a study of the origin and migration of the sexcells of the vertebrates. The number of forms in which this subject has been studied is being constantly extended. While much conclusive work has been done upon the history of these cells in the elasmobranchs, and an equal amount in tracing them in the teleosts, up to this time, they have never been studied in the ganoids. This work was begun over two years ago, and was reported at the 1908 meeting of the Association of American Anatomists in New York. (Allen, '09.)

The material for the present work is obtainable in great plenty within less than half a mile of the grounds of the University of Wisconsin. Since the breeding habits of these two fishes have been thoroughly treated by other writers, it is not necessary to redescribe them. Telleyesniczky's bichromate-acetic fluid and Zenker's fluid have been used as fixing agents and have proved in every way satisfactory. One secret of obtaining good sections is to secure most thorough infiltration by placing the material in a solution of paraffine in turpentine. While turpentine has a bad reputation, no deleterious effects were noted in the course of the work. Paraffine sections were made without difficulty $7 \mu$ and $10 \mu$ thick, and were stained, for the most part, in haemalum and orange G. Heidenhain's iron haematoxylin stain was 
sometimes used for the later stages, but showed no superiority over the haem-alum. In the earlier stages of development it could not be used at all, owing to the deep stain that it gives the yolk material.

With the abundance of material and the amount of time given to the work, it was possible to make a careful study of a large series of stages, much larger than it has been found necessary to use in the preparation of this paper.

It is not necessary to enter into a detailed account of the earlier work upon the origin of the sex-cells, because that has already been done in earlier writings. Since the author's articles on the sex-cells of Chrysemys and of Rana, some important papers have made their appearance, which, with one exception, bear out in a most gratifying manner the conclusions expressed by the writer in the two papers mentioned above and in somewhat less confident manner in the earlier writings of Wheeler, Woods and Beard.

These papers will be discussed in the light of the facts set forth in this paper in the last part of this article, since they are to be considered in a more or less controversial manner.

\section{OBSERVATIONS UPON LEPIDOSTEUS OSSEUS}

Lepidosteus, $4 \mathrm{~mm}$. total length. Cells which appear to be sexcells lie in the ventral portion of the single layered gut entoderm. They can be but dimly distinguished from the other cells of the entoderm among which they lie. They have a more spherical shape than the other entoderm cells, never being flattened as the neighboring cells frequently are. Another difference lies in the fact that the sex-cells contain more and decidedly larger yolk spherules than do the adjoining entoderm cells. Unfortunately these differences are masked by the large quantities of yolk found in the entoderm at this stage. This is true to so great an extent than one can not be certain at this stage as to the identity of the cells in question. At this period the hind gut has a much greater diameter than it has at later stages. At a point onequarter the distance from its cranial to its caudal end it has a 
dorso-ventral dimension of $.24 \mathrm{~mm}$. and a transverse diameter of $.20 \mathrm{~mm}$.

Lepidosteus $6.8 \mathrm{~mm}$. total length. In a similar part of the hind gut of a specimen $6.8 \mathrm{~mm}$. in length the dorso-ventral dimension of the gut endoderm is $.084 \mathrm{~mm}$. while the transverse dimension is $.056 \mathrm{~mm}$. The total length of the hind gut in this later stage is $1.70 \mathrm{~mm}$. as compared with .76 in the $4 \mathrm{~mm}$. embryo. It is seen that there has been a very decided diminution in the diameter of the gut, and, furthermore, that this is out of propontion to the increase in length. It is correlated with a thickening of the gut wall, due to the drawing together of the component cells.

In the $4 \mathrm{~mm}$. stage the gut entoderm was composed of a single layer of cells, while in the $6.8 \mathrm{~mm}$. stage under consideration its lateral and ventral portions are made up of two, and in some places three irregularly arranged layers of cells, while the dorsal wall is made up of a single layer as in the $4 \mathrm{~mm}$. stage. Two series chosen from several of this stage may be taken as showing typical differences. Both show an advance over the preceding stages in the greater ease with which the sex-cells may be distinguished. This is due to the contrast between the ordinary entoderm cells in which a considerable amount of the yolk material has been absorbed and the more rounded yolk-filled sex-cells. In neither embryo has the process of sex-cell migration commenced. This is clearly evident in one, while in the other there are a very few scattered yolk-filled cells of rather problematical character in the loose mesenchyme above and at the sides of the gut entoderm. One striking individual difference between these two specimens is found in the fact that while in one the sex-cells have retained their primitive position in the ventral and lateral portions of the gut entoderm, in the other they have migrated up into its dorsal portions. Although it is somewhat difficult to establish with absolute certainty this migration from the ventral to the dorsal portions of the gut entoderm owing to the difficulty of distinguishing the sex-cells in the preceding stages, the individual differences in this regard observed in this stage, together with the fairly reliable observations upon earlier stages seem to point to an actual migration of this character. 
Lepidosteus $7.3 \mathrm{~mm}$. total length. In the single series of 7.3 $\mathrm{mm}$. embryos the sex-cells in general still occupy the ventral and lateral portions of the gut entoderm, having come to lie in the dorsal wall at only a few points, especially toward the cranial end of the hind gut. A very few sex-cells are found to have migrated into the loose mesenchyme between the gut entoderm and lateral plates of mesoderm, occupying positions in it lateral and dorsal to the latter. These migrant cells are merely the precursors of a general migration which does not become conspicuous until the embryo has reached a length of $8.5 \mathrm{~mm}$.

TABLE 1

Number of sex-cells in Lepidosteus

\begin{tabular}{|c|c|c|c|c|c|c|}
\hline \multirow{2}{*}{ STAGE } & \multicolumn{5}{|c|}{ NUMBER } & \multirow{2}{*}{ TOTAL } \\
\hline & Entoderm & \multicolumn{4}{|c|}{ Mesoderm } & \\
\hline $\begin{array}{l}m m . \\
6.8\end{array}$ & No count & \multicolumn{4}{|c|}{15} & \\
\hline 8.6 & a & \multicolumn{4}{|c|}{73} & \\
\hline 9.2 & $"$ & \multicolumn{4}{|c|}{136} & \\
\hline $9.3 \mathrm{~A}$ & $"$ & \multicolumn{4}{|c|}{41} & \\
\hline $9.3 \mathrm{~B}$ & 《 & \multicolumn{4}{|c|}{311} & \\
\hline $9.3 \mathrm{C}$ & $" 6$ & \multicolumn{4}{|c|}{425} & \\
\hline \multirow[t]{2}{*}{10.7} & 133 & \multicolumn{4}{|c|}{674} & 807 \\
\hline & & Int. & Root & R. & I. & \\
\hline 12.0 & 125 & 104 & 163 & 180 & 179 & 751 \\
\hline 14.1 & 128 & 222 & 37 & 197 & 153 & 737 \\
\hline 17.0 & No count & & & 262 & 235 & \\
\hline 18.0 & “ & & & 171 & 173 & \\
\hline 24.0 & 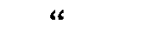 & & & 147 & 154 & \\
\hline
\end{tabular}

Root-Root of mesentery.

R.-Right sex-gland.

L.-Left sex-gland.

Lepidosteus, $8.6 \mathrm{~mm}$. total length. Passing over several intermediate stages studied, the conditions found in a specimen $8.6 \mathrm{~mm}$. long may be described. At this stage the lateral plates of mesoderm are just beginning to split and to form the coelomic cavities (fig. 7). The interval between the plates is filled with loose mesenchyme, of which that portion lying between the gut entoderm and the aorta will later be condensed by the apposition of the lateral plates of mesoderm in formation of the mesentery. 
It will be seen by comparing the figures drawn to scale that the mesentery is at this stage not only relatively but actually much thicker than it is during later stages. The accompanying table serves to show the number of sex-cells and their distribution in certain stages.

In this specimen 73 sex-cells have already migrated out of the gut entoderm into the surrounding mesoderm tissues. While most of them have migrated upward into the loose mesenchyme and splanchnopleuric mesoderm of the anlage of the mesentery, a few have passed laterally into the portions of the splanchnopleuric mesoderm that enter into the formation of the intestinal wall. While the migration of the sex-cells is seen to be well under way at this stage, the great majority of them still remain in the dorsal portion of the gut entoderm. Very few, indeed, are to be found in the ventral half at this stage. The sex-cells of the gut entoderm are easily distinguishable from the other entoderm cells; the latter have lost very nearly all of their yolk material and have become cylindrical in shape. These features stand out in sharp contrast to the large yolk content and spherical form of the sex-cells.

The migration of sex-cells from the gut entoderm into the mesenchyme dorsal or lateral to it may be clearly seen at a few points, as illustrated in figs. 7 and 8 . They retain for the most part their spherical form, but cases like that shown in fig. 7 can be readily found. The shape of this sex-cell clearly indicates the mode of progression. They, undoubtedly, pass through the loose network of mesenchyme by an amoeboid movement, however slow or intermittent it may be.

In this stage sex-cells are found in the hind gut from its cranial end to within $.2 \mathrm{~mm}$. of the cloaca, a distance of $2.6 \mathrm{~mm}$.

Lepidosteus $9.2 \mathrm{~mm}$. long. The number of sex-cells that have migrated out of the gut entoderm is 136 in this specimen. The number of these is still increasing but solcly by migration from the entoderm, since there is no evidence of division of the sexcells during these stages of sex-cell migration.

In this stage the coelomic cavities have appeared in the dorsal portion of each lateral mesodermal plate and the mesentery is 
consequently much more clearly defined. In three specimens $9.3 \mathrm{~mm}$. long the following counts of sex-cells outside of the gut entoderm were made:

$$
\mathrm{A}=41 \quad \mathrm{~B}=311 \quad \mathrm{C}=425 .
$$

A and $C$ are extreme cases, indicating that the process of migration is an irregular one in point of time. The mesentery in specimen $\mathrm{A}$ is $.46 \mathrm{~mm}$. wide.

In specimen $\mathrm{C}$ those sex-cells destined to migrate out of the entoderm have for the most part already done so, while in $A$, an embryo of the same stage, the process is just beginning. The coelome is least developed in $A$ and furthest advanced in C. This would indicate that the extent to which the migration of sex-cells has been carried on is correlated with the degree of development of the mesentery, resulting from the enlargement of the coelomic cavities. While these three specimens belong, no doubt, to slightly different stages of development, they wcre very carefully matched as to length, and are most certainly of the same age.

Lepidosteus $10.7 \mathrm{~mm}$. total length. At this period of development, the mesentery is well formed, being much thinner $(.18 \mathrm{~mm}$.) than in the $9.3 \mathrm{~mm}$. stage. This results in its possessing a denser texture (fig. 9). The great majority of the sex-cells are scattered through the mesentery, showing no definite arrangement; but lying for the most part in the mesenchyme enclosed between the somewhat denser splanchnic layers of mesoderm. A few are found in the mesodermal layers of the intestine, while a fairly considerable number have remained in the gut entoderm. At this time such sex-cells as are found in any but the dorsal wall of the intestine, at its junction with the mesentery, are most probably destined to remain in their present positions. A few of the sex-cells have migrated to places immediately dorsal and lateral to the root of the mesentery. The latter may be considered to have reached the sex-gland anlagen, although their position relative to the root of the mesentery will be shifted, as we shall see, in the later stages, probably by a general shifting of the tissues in which they lie. 
The number of sex-cells which have migrated from the entoderm is found to be 674 . It can be fairly taken as the number destined to undergo migration from the entoderm in this particular individual. Those still remaining in the cntoderm number 133.

it few scattered sex-cells are found as far forward as the cranial end of the hind gut. The latter is $3.41 \mathrm{~mm}$. in length. Opposite to the cranial portion of the hind gut the sex-cells are rather sparse, increasing in number as one follows the series caudally. They become most numerous a short distance caudal to a point two-thirds the distance from the cranial to the caudal end of the hind gut. The last one in the mesoderm is found at a distance of $.46 \mathrm{~mm}$. from the cloaca, and the last one in the entoderm lies at a point $.27 \mathrm{~mm}$. from the cloaca.

Lepidosteus $12 \mathrm{~mm}$. total length. At this period migration of the sex-cells has progressed to the point where most of them have reached their final positions. They are still to be seen in the entoderm. This number (125) is quite close to that (133) of the similarly situated sex-cells of the preceding stage. The density of the mesodermal tissues surrounding the gut entoderm makes it seem quite unlikely that any more sex-cells could migrate into them from this source.

The distribution of the sex-cells is as follows:

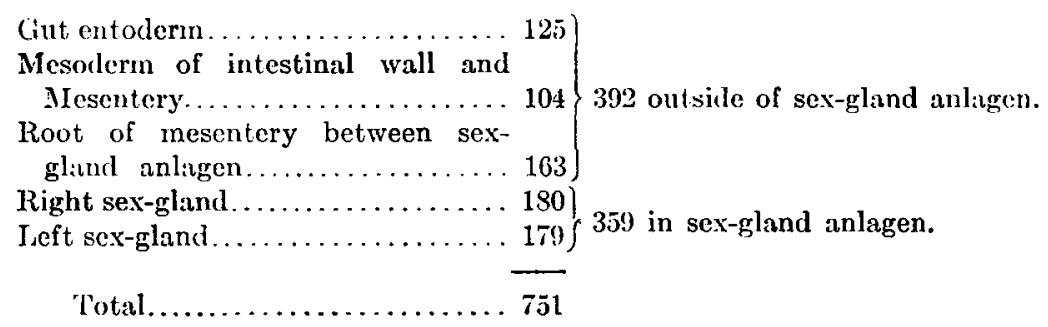

The table may be allowed to speak for itself. The sex-gland anlagen grade into one another by an intermediate region at the root of the mesentery. More or less arbitrary limits had to be assumed to distinguish between these three regions. In later stages, illustrated by the $17 \mathrm{~mm}$. stage, fig. 11, we shall see 
that the sex-cells undergo lateral migration, either apparent or real, so as eventually to lie at some distance on each side of the median point.

The narrowest portion of the mesentery is at about one-quarter the distance from its origin to its insertion. Its minimum width, as measured here amounts to $.028 \mathrm{~mm}$., thus showing a great reduction as compared with the $10.7 \mathrm{~mm}$. stage. This reduction in width is shared by the entire mesentery, certain regions remaining broad only on account of the enclosed blood vessels. No doubt the migration of the sex-cells out of the mesentery is in large part responsible for this, but a considerable share of it must be ascribed to the fact that there has been a tendency for the tissues to become more compact.

The total length of the hind gut at this stage has reached 4.03 $\mathrm{mm}$. Sex-cells are found in the entoderm at its cranial end, and from there extend to within $0.62 \mathrm{~mm}$. of the cloaca. The distribution of sex-cells within the sex-gland anlagen is somewhat more restricted, since they extend from a point $0.31 \mathrm{~mm}$. caudal to the beginning of the hind gut, to a point $1.00 \mathrm{~mm}$. cranial to the cloaca. They are rather sparse at these two extremes.

As in the preceding stages, there is no clear evidence of division of the sex-cells, although one can not be absolutely certain upon this point. While at this time many are free from yolk material, others show but little diminution of it. It is true that the sexcells are often found arranged in clusters, but there is no evidence to show that these are due to repeated division of a parent cell rather than to a tendency for them to congregate through mutual attraction. What the nature of this attraction might be, we do not know; but it might well be akin to that influence which causes the sex-cells to migrate toward the sex-gland anlagen from their source. Similar clusters of sex-cells were found in early stages in Chrysemys.

Lepidosteus $14.1 \mathrm{~mm}$. total length. Little radical change is to be seen in this stage. The sex-cells were counted and gave the following results: 


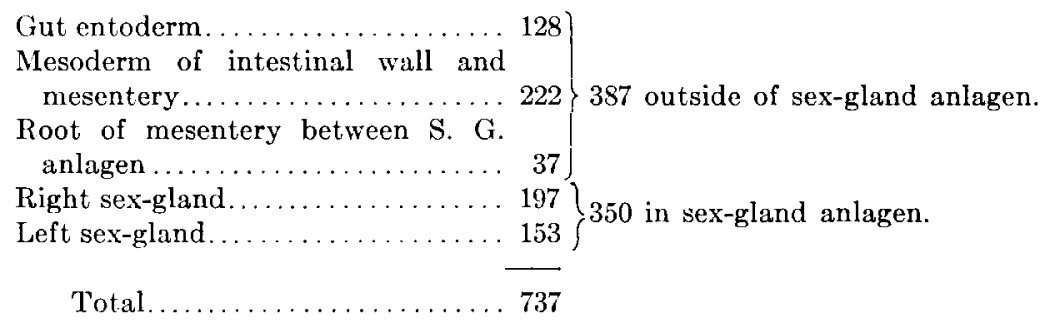

There is a strikingly close correspondence between the results of the count in this specimen and those in the preceding one. Attention may be called to the fact that in this specimen a materially greater number of sex-cells is found in the right sexgland than in the left. At the same time there is a very close correspondence in the total number of sex-cells that have reached the sex-gland anlagen as compared with the total number in the $12.0 \mathrm{~mm}$. stage (359).

Lepidosteus $17 \mathrm{~mm}$. total length. In this specimen those sexcells destined to occupy the sex-glands are seen to have migrated some distance to each side of the root of the mesentery, fig. 11. Their position relative to the root of the mesentery and to the Wolffian duct varies at different points along the sex-gland anlage. In the most cranial portion of the latter they lie just medial to the Wolffian duct. As one follows the sex-glands caudally, the sex-cells are found to lie closer and closer to the mesentery, being situated midway between the latter and the Wolffian duct in the middle region of the sex-gland anlage. The most caudally situated sex-cells lie close to the root of the mesentery.

In this and the succeeding stages the intestine had become so voluminous as to make the counting of the sex-cells in its walls very difficult and inaccurate. It is in fact not easy to distinguish them from the cells of the gut entoderm because of their rather small size and their entire lack of yolk material at this stage.

The total number of sex-cells in the sex-gland anlagen of this specimen is rather high, there being 235 in the left sex-gland and 262 in the right. The total number is 497 . 
The slightly greater number of sex-cells in the sex-glands of this specimen as compared with that in the previous ones is of little significance. It most certainly does not indicate that there has been any extensive division of them. In a previous work upon Chrysemys, (Allen '07), it was shown that there was an extreme amount of individual variation in the number of sex-cells. This variation in Lepidosteus is relatively slight compared with that observed in Chrysemys. In a specimen slightly older than this stage $(18 \mathrm{~mm}$.) there were 171 sex-cells in the right sex-gland, and 173 in the left one, the total number, 344, being not far from the average.

In these two stages, 17 and $18 \mathrm{~mm}$., the sex-colls usually occur singly, although in places they are aggregated into clumps so thick as sometimes to show as many as five or six in a section of one of the sex-glands. Whether the sex-cells occur singly or in clumps, they are surrounded by peritoneal cells which contribute materially to the formation of the ridge-like anlage of the sex-gland.

Lepidosteus $24 \mathrm{~mm}$. total length. In a specimen of this length, fig. 12, there is no essential advance in the development of the sex-gland. There were 147 sex-cells in the right sex-gland, and 154 in the left one. The total number, 301, is distinctly below the average.

Comparison with other forms leaves no room for doubt as to the identity of these sex-cells. Since the aim of this paper is merely to trace out their origin, we will not follow them through later stages in their history, but will describe the conditions found in a specimen $110 \mathrm{~mm}$., in length, fig. $13 . \quad$ A complete series of sections through the sex-gland region of this specimen was not made, so it is impossible to give a full account as to the number of sex-cells and general condition of the sex-gland at this time. In running through the series one is struck with the sparseness of the sex-cells. Never are more than two or three to be found in a single section, and often none at all. This would lead one to infer that there has been little or no multiplication of the sexcells even at this late stage of development. 
A glance at table 2 shows that there is a general tendency to a reduction in the average size of the cell body in the later stages. This may be due to the absorption of the contained yolk material. There is no marked change in the size of the nucleus.

TABIE: 2

Dimensions of sex-cells of Lepidosteus

\begin{tabular}{|c|c|c|c|c|}
\hline \multicolumn{5}{|c|}{ CELL BODY } \\
\hline Stage & Nucleus & IAKCEST & SNALIEST & AVERAGE \\
\hline $\begin{array}{c}m m . \\
8.6\end{array}$ & $6.0 . t$ & 15.10 & $12.0 \mathrm{~S}$ & 13.74 \\
\hline 9.3 & 6.04 & $1 S .12$ & $12.0 \mathrm{~s}$ & $14.9 j$ \\
\hline 10.7 & (i. 04 & 15.10 & 11.32 & 13.59 \\
\hline 14.0 & 5). $\$ 1$ & $12.0 \mathrm{~S}$ & 9.06 & 10.27 \\
\hline 17.0 & 6.04 & 13.59 & 9.06 & 11.63 \\
\hline 24.0 & 5.81 & 9.06 & 7.55 & 8.65 \\
\hline 110.0 & 6.53 & $14 . \bar{x}(0$ & 9).29 & 12.40 \\
\hline
\end{tabular}

AMIA CALVA

Amia $4 \mathrm{~mm}$., total length. In the text figure $\mathrm{A}$ is shown a transverse section of an Amia larva of this stage. It will serve as a starting point from which we shall proceed to consider still earlier stages in tracing out the earliest phases in the origin and migration of the sex-cells. The section shown is taken just anterior to the hind gut, the gut entoderm being clearly marked by its greater thickness and dorsal curvature. The cavity of the intestine at this point opens into the large sub-germinal cavity. The extra embryonic portions of the entoderm, i.e., those which do not form part of the anlagen of the alimentary tract and its appendages can logically be divided into four different regions: (1) The roof of the sub-germinal cavity which is distinguishable from the gut entoderm, as indicated; (2) The layer forming the floor of the sub-germinal cavity; (3) The peripheral layer of entoderm lateral to the sub-germinal cavity (peripheral entoderm); (4) The central yolk mass, or vitellus (vitelline entoderm). In the first three of these regions the cells are arranged in a single layer. They are characterized by the fact that the yolk spherules of the component cells are distinctly smaller than are those of 
the vitellus, their diameter being from one-quarter to one-half of that of the typical spherules to the vitellus. In the latter cells are scattered a few of these smaller yolk spherules; but the distinction between the first three divisions of the entoderm and the vitellus is a very sharp one.

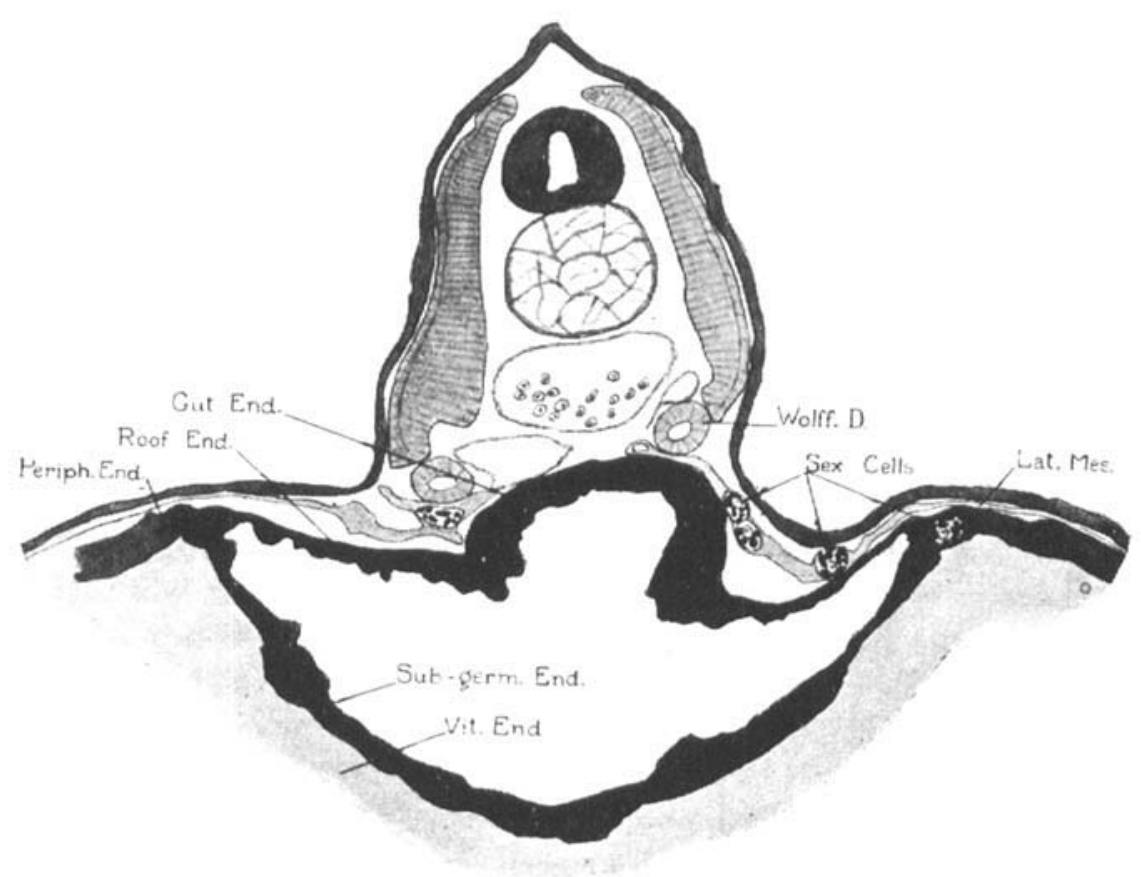

Text figure A

In connection with this distinction it is interesting to note that the yolk spherules along the cleavage planes that cut through the vitellus are found to belong to this small type. It is easy to see that if the vitellus were cut up into cells as small as those comprising portions 1,2 , and 3 of the entoderm, the thickness of the layers of small spherules which form merely a border to the large cells would be so great as to comprise the entire body of the more finely divided ones. This difference in the size of the 
yolk spherules is then probably associated with the difference in the size of the cells. The peripheral entodermal layer which we have designated as division three is interrupted lateroventrally by blood vessels lying in the mesoderm.

The lateral plates of mesoderm have long since broken away from the mesoblastic somites. Their inner margins lie at some distance to each side of the median line. While there is the slightest tendency in places for the splanchnic and somatic layers of mesoderm to split apart along the medial margins of the lateral plates, the remainder of the lateral plates show no indication of a splitting, even in the arrangement of the nuclei. It is, however, quite probable that such a plane of cleavage is already laid down. This is shown by the sex-cells (text fig. A) being imbedded in the lateral plates. When the somatopleure and splanchnopleure separate later, these will be found to lie in the coelomic cavity, being for a time merely adherent to the coelomic surface of the medial portion of the somatic mesoderm. One can fairly assume that during the period of migration, represented by fig. 5, the sex-cells push their way between the two layers of mesoderm following the potential cleft that separates them.

Text fig. A is very suggestive, as it shows sex-cells situated at intervals from a point just beyond that at which the roof and floor entoderm join the peripheral entoderm. The path of their migration is thus clearly marked out. In this figure it should be noted that the most laterally situated sex-cell lies in the entoderm, while all of the others are clearly imbedded in the lateral plates of mesoderm as already indicated. In but one or two of the many specimens examined were there any sex-cells found in the roof or gut entoderm. They arise in the peripheral entoderm from which they migrate into the lateral plates of mesoderm and through them to their medial borders, whence, as I shall later show, they pass into the sex-gland anlagen after the formation of the coelomic cavity.

The total number of sex-cells found in the mesoderm of the specimen of this stage was 87 . Of these 40 were found on the right side and 47 on the left. Text fig. A will indicate their distribution. 
Table 3 serves to show for purposes of comparison the numbers of sex-cells found in different specimens of Amia.

TABLE 3

Number of sex-cells in Amia calva

\begin{tabular}{|c|c|c|c|c|c|}
\hline \multirow{2}{*}{\multicolumn{2}{|c|}{ STAGE }} & \multirow{2}{*}{ BPACIMIN } & \multicolumn{3}{|c|}{ NOMBER OF BEX-CELLS IN MESODERM } \\
\hline & & & R. & L. & Total \\
\hline $\begin{array}{c}\text { Hours. } \\
132\end{array}$ & $m m$. & A & None & None & 0 \\
\hline 132 & & B & None & None & 0 \\
\hline 132 & & C & None & None & 0 \\
\hline 132 & & $\mathrm{D}$ & None & None & 0 \\
\hline 137 & & A & 7 & 4 & 11 \\
\hline 137 & & B & 9 & 7 & 16. \\
\hline 137 & & C & 21 & 8 & 29 \\
\hline 147 & & $\mathbf{A}$ & 15 & 7 & 22 \\
\hline 147 & & B & 14 & 17 & 31 \\
\hline 147 & & C & 22 & 11 & 33 \\
\hline 147 & & $\mathrm{D}$ & 48 & 18 & 66 \\
\hline 147 & & $\mathrm{E}$ & 39 & 28 & 67 \\
\hline 147 & & $\mathbf{F}$ & 50 & 26 & 76 \\
\hline \multirow[t]{20}{*}{155} & 3.0 & & 15 & 34 & 49 \\
\hline & 3.4 & & 62 & 41 & 103 \\
\hline & 3.5 & A & 39 & 53 & 92 \\
\hline & 3.5 & B & 59 & 48 & 107 \\
\hline & 3.7 & A & 42 & 30 & 72 \\
\hline & 3.7 & B & 45 & 47 & 92 \\
\hline & 4.0 & & 40 & 47 & 87 \\
\hline & 5.0 & & 23 & 20 & 43 \\
\hline & 5.6 & & 42 & 56 & 98 \\
\hline & 6.0 & & 28 & 34 & 62 \\
\hline & 7.0 & & 38 & 36 & 74 \\
\hline & 7.6 & & 33 & 42 & 75 \\
\hline & 9.1 & & 36 & 40 & 76 \\
\hline & 11.4 & & 28 & 54 & 82 \\
\hline & 15.0 & A & 28 & 49 & 77 \\
\hline & 15.0 & B & 38 & 45 & 83 \\
\hline & 16.0 & A & 19 & 14 & 33 \\
\hline & 16.0 & B & 22 & 17 & 39 \\
\hline & 16.0 & C & & & 99 \\
\hline & 23.7 & & 47 & 55 & 102 \\
\hline
\end{tabular}

This stage is a convenient starting point from which to proceed in the study of earlier stages. 
A mia $3.7 \mathrm{~mm}$. total length. The conditions are, in the main, quite similar to those found in the $4 \mathrm{~mm}$. stage. In one of the two specimens (B) in which the sex-cells were counted there were 92 sexcells in the mesoderm and 10 in the entoderm. Although this total number of 102 is greater than the number found in the 4 $\mathrm{mm}$. stage (87), yet, as shown in table 2 , no significance is to be attached to this on account of the great individual variation in the number of sex-cells observed, not only in Amia, but also shown by the author to be so obvious in the turtle, Chrysemys. In $A$ of this stage, 72 sex-cells were found, 42 on the right and 30 on the left side.

Amia $3.5 \mathrm{~mm}$. total length. Two larvae of this stage were studied. It was rather difficult to measure the specimens accurately, owing to the fact that the caudal portion of the body free from the yolk has a strong ventral bend. It can be straightened out only in later stages. The two specimens of this length were taken from the same nest and both are distinctly younger than the preceding, yet they showed decided differences from one another in the positions occupied by the sex-cells, probably owing to the fact that this, in all likelihood, is the period of their most active migration. In specimen $A$ the sex-cells are quite numerous in the portion of the lateral plate of mesoderm, which lies immediately above the border of the subgerminal cavity. They occur in fair numbers in the mesoderm between this region and a point one-half the distance from this point to the median edge of the lateral plate of mesoderm. Only three were found nearer the median line than this. Of these, one had scarcely passed the midway point, one was still some distance from the median edge of the lateral plate, while one had actually reached that point.

In specimen $B$ of this stage a large proportion of the sex-cells have reached the median edge of the lateral plate of mesoderm of each side. This is especially noticeable on the right side. The conditions in this specimen approach those described for the $4 \mathrm{~mm}$. stage but do not show quite such an advanced condition, owing to the fact that a larger proportion of sex-cells are scattered along the outer portions of what we may call the sex-cell path. There 
were noted two or three instances in which the sex-cells were migrating from the peripheral entoderm into the mesoderm.

A mia, $3 \mathrm{~mm}$., total length; 155 hours. In a specimen of $3.0 \mathrm{~mm}$. total length, the free caudal portion has but recently separated from the vitelline mass, and has attained a total length of $.56 \mathrm{~mm}$. By comparison with a number of embryos of 132, 137, and 147 hours old, the age of this embyro was estimated to be very close to 155 hours. This estimate was made by counting the number of sections passing through the posterior part of the embryo free from the yolk mass. Sufficient numbers of embryos were used to give a fairly accurate determination, there being seven specimens of the 147-hour, three of the 137-hour, and two of the 132-hour stages studied.

TABLE 4

The numbers of sex-cells in each were as follows:

\begin{tabular}{|c|c|c|c|}
\hline & RIGRT BIDE & LEFT SIDE & TOTAL \\
\hline $\operatorname{In} A \ldots \ldots \ldots \ldots$ & 39 & 53 & 92 \\
\hline In B............ & 59 & 48 & 107 \\
\hline
\end{tabular}

There were 49 sex-cells counted in the $3 \mathrm{~mm}$., 155-hour embryo. This, it will be seen, is decidedly below the average and yet the number is greater than that found in the $5 \mathrm{~mm}$. stage and in the much later $16 \mathrm{~mm}$. specimens.

Only two of the sex-cells have migrated a very short distance along the lateral plate of mesoderm, beyond a point overlying the lateral boundary of the subgerminal cavity; the remainder of them all lie lateral to it. It will thus be seen that they show a much earlier phase of migration than that observed in the 3.5 mm. embryo, not only as regards the number that have migrated into the mesoderm, but likewise in the distance through which they have travelled in their journey in that layer toward the sexgland anlagen.

Amia, $147 \mathrm{hr}$. stage. That there is a great amount of individual variation in the rapidity with which this migration from the peripheral entoderm to the lateral plates of mesoderm is accomplished may be readily seen by referring to the numbers counted 
in the mesoderm of seven specimens of the 147 hour stage. These specimens were all taken from the same nest and kept in the same dish, so there can be but very slight difference in their ages, due, if it exists, to the small difference in the time at which the eggs were laid. It will be seen that the total number of sexcells in the entoderm in these specimens varies from 22 to 76 . The latter number is not only greater than that observed in the $3 \mathrm{~mm}$., 155 hour stage, but almost equals that counted in many specimens of older stages after migration has been completed, as, for instance, the $114 \mathrm{~mm}$ and $15 \mathrm{~mm}$. stages (see table). In this stage clearly defined sex-cells can be seen in the peripheral entoderm just below the lateral plates of mesoderm, figs. 16 and 17. These cells are distinguishable from the other entoderm cells among which they lie, by the greater size of their contained yolk granules as contrasted with the small size of the yolk granules in the other cells that make up this layer. The difference is further marked by the more rounded form of the sex-cells. Comparison of these sex-cells in the peripheral entoderm shows them to be identical with other more clearly defined sex-cells in the mesoderm. Of this identity there can be no question, and it is equally clear, from a study of later stages, that these cells, having once migrated into the lateral plates of mesoderm, pass unaltered along the latter to come finally to rest in the sex-gland anlagen. There can be no doubt about the origin of the sex-cells from the entoderm. A number of cases were observed in which the sexcells were actually in process of passing from the peripheral entoderm into the lateral plates of mesoderm.

At this stage, sex-cells have a wide distribution in the peripheral entoderm, being scattered through a region extending from a point opposite to the region where the blood cells originated to the junction of the peripheral, sub-germinal and roof entoderm. In three specimens of the 137 hour stage, conditions are quite similar to the foregoing. In these embryos the number of sexcells ranged from 11 to 29 . It will be seen that the maximum number of sex-cells counted in this stage is greater than the minimum number of the 147 hour stage, although in all three of these 137 hour embryos, the caudal end of the embryo, that part 
that has been lifted off the yolk, is decidedly shorter than in any of the 147 hour specimens.

Amia, 132 hr. stage. In four specimens of the 132 hour stage, the caudal end of the embryo was just ready to undergo separation from the yolk. Only in one of them had this really commenced, the separated portion having reached a length of but $20 \mu$. Not one of these four specimens showed a single sex-cell in the mesoderm. There can be no question upon this point because they could be very readily detected if present. In the 137 and 147 hour stages those that migrated into the mesoderm stand out most clearly and sharply from the surrounding mesodermal cells. The points of difference between the two kinds of cells are very striking and unmistakable. The sex-cells on the one hand are large, spherical, have sharply defined boundaries, and are filled with large oval yolk grains; while the mesodermal cells are small, flattened, syncytial, and contain a very few minute yolk granules.

It is very much more difficult to trace the earlier history of the sex-cells in the peripheral entoderm, owing to the slight differences that may be taken as criteria in distinguishing them from the neighboring entoderm cells. Numbers of cells with all the characteristics of sex-cells are found just beneath the anlagen of the blood masses. This stage is just before the development of blood vessels within the embryo, and the blood-forming cells occur in the form of two sharply limited bands, one on each side of the embryo and at some distance lateral to it. Here and there, sex-cells are found in the peripheral entoderm, medial to these areas; but clearly defined cases of this sort are rather rare as compared with the large number seen in this region a little later in the 147 hour stage. It is quite likely that many of these sex-cells are overlooked at this stage owing to the fact that the neighboring entodermal cells contain rather large yolk grains at this time, while those seen in these cells in the 147 hour stage are much smaller than at this stage.

It is quite possible that the sex-cells may migrate medially in the entoderm from an entodermal source beneath the blood anlagen to various points between this region and the edge of the sub-germinal cavity. It is possible that a large proportion 
of them may have developed in the peripheral entoderm throughout this entire extent. On the other hand, it is also possible that sex-cells may migrate up into this region from the central entoderm beneath.

We have traced the history of the sex-cells from the $4 \mathrm{~mm}$. stage where they are readily identified by any one who has had any experience in observing these cells, back to the earliest stage at which they are distinguishable in the entoderm. We shall now follow them up to the period when they are enclosed in the definitely formed sex-glands and finally to the stage at which they are found to have begun to increase in number.

Amia $5 \mathrm{~mm}$., total length. Passing from the $4 \mathrm{~mm}$. stage to the next represented in our series, $5 \mathrm{~mm}$., we find that the sexcells have made but little progress in their migration toward the median edge of the lateral mesodermal plates. The total number of sex-cells counted in this stage was surprisingly small, being 43 as compared with 87 in the $4 \mathrm{~mm}$. stage. This difference in number is probably due to individual variation. The hind gut has materially lengthened, being $1.3 \mathrm{~mm}$. in length, compared with $.88 \mathrm{~mm}$. in the $4 \mathrm{~mm}$. stage. There has been a corresponding increase in the length of the region over which the sexcells are distributed. In the $4 \mathrm{~mm}$. stage they extend from a point $0.06 \mathrm{~mm}$., in front of the beginning of the hind gut, caudally to a distance of $0.35 \mathrm{~mm}$. In the $5 \mathrm{~mm}$. stage that we are considering, this region begins at the same point relative to the hind-gut and extends caudally for $0.50 \mathrm{~mm}$., one isolated sexcell being found at a distance of $0.57 \mathrm{~mm}$. behind the cranial limit of their distribution.

In the more caudal portion of this region the splanchnic and somatic layers of mesoderm have begun to separate to form the coelome. This separation does not at first lead to the formation of a continuous cavity but rather to a series of isolated, somewhat rounded cavities. Further caudad, the coelome becomes more and more completely developed, appearing as a large cavity on each side.

Amia $6 \mathrm{~mm}$., total length. At this time the first sex-cells appear in the splanchnopleure just at the entrance of the hind gut. 
The first sex-cells in the somatopleure are found in the sex-gland anlagen a short distance $(0.04 \mathrm{~mm}$.) behind this point. The sexcells are distributed somewhat irregularly from the cranial end of the hind-gut to a point $0.90 \mathrm{~mm}$., caudad to this point and there are a few scattering sex-cells still further caudad than this.

The coelome is apparent as a continuous cleft on either side of the hind-gut along the entire extent of the region occupied by the sex-cells. The majority of the sex-cells are to be found in the dorso-medial extremity of the coelome, i.e., near the root of the mesentery. A few lie lateral and ventral to the intestine. The coelomic cleft has not as yet become wider than the diameter of the average sex-cell and we consequently see them usually bridging across it, fig. 18. In no case have they penetrated into the somatic mesoderm as we find them doing later. One sex-cell was found in the gut-entoderm, whither it may have migrated from the mesoderm. It is, on the other hand, quite possible for it to have migrated in the entoderm in the manner of sex-cell migration in the turtle. This is a point of minor significance and an occurrence which is at best very infrequent. Amia, $7 \mathrm{~mm}$., total length. $\mathrm{Up}$ to this time, the mesentery has been only potentially present, the two lateral plates of mesoderm being in contact above the gut-entoderm. Now, however, we find that it has begun to elongate and become thin. This is naturally correlated with the increase in the extent of the coelome, fig. 19. Two well defined sex-cells are found in the gut-entoderm, $0.06 \mathrm{~mm}$., cranial to the opening of the hind-gut. These are to be interpreted in the same way as the cell in the entoderm mentioned above. The first sex-cell occurring in the mesoderm is found $0.08 \mathrm{~mm}$. caudad to the beginning of the hind-gut. The sex-cells are distributed through a region extending from a point immediately back of the opening of the hind-gut to a point 1.05 mm. behind it, with a few scattering ones behind these. The total number of sex-cells is 74 .

Amıa, 9.1 stage. Sex-cells first appear $.18 \mathrm{~mm}$. cranial to the opening of the hind-gut. They extend from this point to a point $1.59 \mathrm{~mm}$. caudad to this, giving a total extent of $1.67 \mathrm{~mm}$. The total number of scx-cells counted at this stage amounted to 
76. Of these all were in the sex-gland anlagen except three; one of which occurred in the gut-entoderm and two in the parietal peritoneum. I am inclined to consider it unlikely for these misplaced sex-cells to reach the sex-glands. One is struck, however, with the great difference in the relative number of misplaced sexcells in Amia as compared with Lepidosteus. This may be apparent rather than real, owing to the possibility that in Amia large numbers of them may have failed to migrate from the entoderm into the mesoderm during early stages. Owing to the difficulty of certainly distinguishing sex-cells in the entoderm from ordinary entoderm cells, it was quite impossible to make any count of those left behind in migration. All but a very few, however, that reach the mesoderm succeed, as we have seen, in reaching the sexgland anlagen. A considerable number of cells seen in the entoderm in later stages contain small yolk spherules and show other points of resemblance to sex-cells. In this stage the mesentery has become quite lengthened and the coelome very large. The sex-cells have penetrated into the root of the mesentery, fig. 20.

The sex-cells, with rare exceptions, still contain large quantities of yolk material. In these exceptional cases a finely granular appearance gives at least the suggestion of small unstained yolk spherules. The yolk appears in the shape of particles varying in size from small granules up to large lemon-shaped pieces quite as large as those with which the cells of the yolk entoderm are so completely filled.

Amia 11.4 mm., total length. The sex-cells are fairly numerous over a region $1.85 \mathrm{~mm}$. in length, beginning at a point $0.06 \mathrm{~mm}$. back of the yolk stalk and ending at a point $0.85 \mathrm{~mm}$. cranial to the cloaca. Two isolated sex-cells are found caudad to the point named, one of them occurring very close to the cloaca. Their total number in this embryo is eighty-two. The sex-cells have much the same characteristics as in the previous stage.

This stage is marked by a decided increase in the length of the mesentery and by a decrease in the size of the yolk-sac, which is now but $0.7 \mathrm{~mm}$. in diameter and is greatly hollowed out to form a portion of the intestinal wall. 
While the sex-cells of the $9.1 \mathrm{~mm}$. stage are imbedded in the mesoderm at the root of the mesentery and always close to the median line, they are found in the $11.4 \mathrm{~mm}$. stage to occupy a position a short distance on each side of this point. Not only have they moved laterally, but they have also protruded into the body cavity, accompanied by a few mesoderm cells which are intercalated between them, fig. 21, and surround them with a thin peritoneal investment as well.

Amia $15 \mathrm{~mm}$., total length. In this stage the sex-cells extend over a distance of $2.70 \mathrm{~mm}$. in the caudad $0.50 \mathrm{~mm}$. of which they are very sparse. The sex-glands protrude further into the body cavity than in the preceding stage, and the ligament of attachment becomes narrower. The genital ridge is very much lower in the gaps between sex-cells than it is in the sex-cell regions. In spite of the fact that it may be very low for quite a distance, it is continuous throughout. The genital ridges diverge quite widely at their cranial ends, approaching the median line at a point $.4 \mathrm{~mm}$. caudad to their point of commencement.

The sex-cells have almost uniformly used up their contained yolk material, although a few scattered ones are still closely packed full of them. The sex-cells in specimen A, numbered 28 on the right side and 49 on the left, the total number being 77 . The number of sex-cells in specimen $B$ was 38 on the right side and 45 on the left, the total being 83 .

Amia $16 \mathrm{~mm}$. long. In two $16 \mathrm{~mm}$. larvae, conditions very similar to those of the $15 \mathrm{~mm}$. stage were found. None of the sex-cells contained yolk material in a sufficiently large amount to be clearly recognizable. The striking thing about these two specimens is the very small number of sex-cells present, 33 in one case and 39 in another. There is no indication of degeneration or of a failure to migrate to the proper positions. The case seems to be similar to one cited in Chrysemys, both being due to individual variation.

These two specimens were taken from the same brood and no doubt had the same parentage. Another $16 \mathrm{~mm}$. specimen taken from a different brood showed 99 sex-cells, a number not very far below the maximum. From this fact, and from the 
total absence of any indication of degeneration of sex-cells in these or earlier stages, I feel convinced that this small number does not indicate any tendency to degeneration of sex-cells.

Amia, $23.7 \mathrm{~mm}$. total length. In the next stage studied, 23.7 $\mathrm{mm}$., the sex-cells numbered 102 . Here again there is no evidence of a change in the number of sex-cells originally present. The number, although somewhat high, is exceeded by some of the specimens of very much earlier stages. There is no evidence of sex-cell division nor of any degeneration.

Amia, $40 \mathrm{~mm}$. total length. At this stage the sex-gland is elongated oval in transverse section. It has become bent over in such a way that the proximal edge is medial and the free edge

TABLE 5

Dimensions of sex-cells of Amia

\begin{tabular}{c|c|c}
\hline stage & NUCLEus & CELL Bodx \\
\hline Hours & & \\
137 & 7.10 & 18.03 \\
147 & 6.71 & 18.70 \\
$m m$. & 6.45 & 21.88 \\
3.7 & 6.51 & 17.80 \\
5.0 & 8.00 & 14.96 \\
9.1 & 7.48 & 11.59 \\
11.4 & 7.48 & 12.64 \\
15.0 & 7.74 & 14.06 \\
16.0 & 7.22 & 14.20 \\
23.0 & & \\
\hline
\end{tabular}

lateral in position. The mesodermal cells have increased greatly in number. The peripheral cells have become arranged into a somewhat poorly defined layer, while the sex-cells lie in the interior of the sex-gland. No attempt was made to determine the time at which the sex-cells begin to divide, or to study the further development of the sex-glands.

Measurements of the nuclei and cell bodies of the sex-cells gave the following averages, two diameters being measured in each of five sex-cells chosen at random in each stage.

Although the number of cells measured in each stage is hardly sufficient to justify one in considering these average dimensions 
to have any high degree of accuracy, I feel that we are quite justified in concluding from these figures that: (1) there is a fair decrease in the size of the cell-body as development proceeds, and (2) that there is a slight increase in the size of the nucleus.

The decrease in the size of the cell-body is probably due to the absorption of the yolk material with which the sex-cells are so richly filled during the earlier stages. No good explanation to account for the slight apparent increase in size of the nucleus presents itself.

\section{DISCUSSION OF RESULTS}

We can not consider this work as completed without making a comparison between the sex-cells and the other cells of the embryo. This subject will first be taken up in Amia where we have traced the sex-cells back to earlier stages than in Lepidosteus. It has already been pointed out that the sex-cells, as first seen in the peripheral entoderm, are to be distinguished only by the size and arrangement of the yolk spherules. The nuclei bear a close resemblance to those of surrounding cells of the same size, while the larger nuclei of larger cells show many points of similarity to them. In all except the earliest stages studied, these nuclei are quite rounded. The chromatin appears in the form of slender strands that take a peripheral position in the nucleus. There is invariably a plasmosome present and rarely two of them. In the 147 hour stage the nuclei of the sex-cells bear a resemblance not only to those of the neighboring cells but also to those of the gut entoderm. In fact, many nuclei of the mesoderm show similar characteristics.

After development has gone a little further, as in the $3.4 \mathrm{~mm}$. and $4 \mathrm{~mm}$. stages, the mesodermal nuclei and those of the gut entoderm are found to have become smaller and are more deeply stained than those of the sex-cells and peripheral entoderm. In all of these later stages, which include $5 \mathrm{~mm} ., 6 \mathrm{~mm} ., 9.1 \mathrm{~mm}$., 11.4 $\mathrm{mm}$. and $16 \mathrm{~mm}$. larvae, these differences are found to increase. Although the sex-cells undergo a migration from the peripheral entoderm into the lateral plates of mesoderm and through the latter to the sex-gland anlagen, they still bear a close resemblance 
to certain cells of the peripheral entoderm. This not only involves a similarity of the nuclei but of the dimensions of the cell bodies. This is true even after the sex-cells and the corresponding cells of the peripheral entoderm have lost their yolk through absorption.

In the stage of $11.4 \mathrm{~mm}$., the yolk mass has been greatly reduced (figs. 25 and 26). Only here and there about its periphery are cells to be found with well defined outlines. The great mass is syncytial, with large nuclei of varying size scattered here and there. While these nuclei of the vitelline mass are much larger than the sex-cell nuclei, they bear a close resemblance to the latter. The nuclei of the well defined peripheral cells are practically identical in size and appearance with those of the sex-cells.

While the similarity between sex-cells and between these two classes of cells is not so marked in Lepidosteus as in Amia, yet it appears to be equally true. In the $17 \mathrm{~mm}$. stage (figs. 14 and 15) the yolk mass is still of fair size. There is a layer of peripheral entoderm that is largely made up of cells with clear boundaries, whose nuclei are similar to those of the sex-cells in respect to the presence and character of the plasmosome and in the form and distribution of the chromatin material. In many cases these nuclei are larger than those of the sex-cells; but many are found which are quite as small. These grade into the very large nuclei of the syncytial vitelline entoderm.

At this stage the tissues of the body have taken on their distinctive characters and their component cells have undergone in many cases a high degree of specialization. This emphasizes strongly the similarity between the sex-cells and the cells of the peripheral entoderm.

As we pass back to earlier stages, such as those of $9.3 \mathrm{~mm}$., $5.9 \mathrm{~mm}$., etc., we still find this similarity between these types of cells, although the nuclei of all the body cells tend to show greater and greater similarity to one another in the earlier stages. For instance, it becomes quite difficult to distinguish the nuclei of the gut entoderm cells from those of the sex-cells. Even the nuclei of the Wolffian ducts show quite a close resemblance to the sexcell nuclei during the early stages of development. 
There are two ways of viewing the similarity that the sexcells of Amia and Lepidosteus bear to these cells of the peripheral entoderm. The well defined cells of the peripheral entoderm might be interpreted as sex-cells that have failed to migrate into the lateral plates of mesoderm. It would then remain to give an explanation of the resemblance that the nuclei of these cells bear to the nuclei of the vitelline entoderm and to account for the intermediate types of nuclei by which they grade into one another.

The other view of this problem is to consider sex-cells, peripheral entoderm cells, and vitelline entoderm cells as slightly differentiated blastomeres, dating from an early stage of development, and to consider the similarity that they bear to the cells of the peripheral entoderm as due to the fact that they too have remained in a relatively slightly differentiated condition. This. view seems the more probable of the two. It is by no means a new one, having been advanced by Nussbaum in 1880 .

It would be rash in the extreme to claim that the sex-cells might not differ in some essential chromosomal characters from the cells of the peripheral entoderm which they so closely resemble, and yet careful study has failed as yet to show any real differences. While such differences may exist, these cells all have much in common with one another.

In a recent paper by A. P. Dustin ('07), this author gives a new view of the origin and movements of the sex-cells of Triton alpestris, Rana fusca and Bufo vulgaris. Since his view is so greatly at variance with my own, it will be necessary to review this work in some detail. He begins with an account of the sex-cells of Triton, and stress is laid upon this form, the author showing a strong tendency to bring his studies upon Rana and Bufo into line with his work upon Triton.

He first recognizes the anlage of the sex-cells in the medial portions of the lateral plates of mesoderm in the $3 \mathrm{~mm}$. larva of Triton. They occur only in the caudal half of the body and involve only those parts of the lateral plates of mesoderm lying medial to the Wolffian ducts. In the early stages these cells are filled with large yolk spherules and do not greatly differ from the mesodermal cells that surround them. At a later period the sex- 
cell anlagen are pushed together in the median line, between the aorta and the roof of the archenteron. They fuse into a median longitudinal rod of cells lying just above the dorsal root of the mesentery. By this time the sex-cells have lost their yolk material and have, to a large extent, assumed their definitive character. During these stages the number of the sex-cells has increased from one hundred to one hundred and fifty, occasional mitoses being observed. Soon after this stage of the median anlage $(9 \mathrm{~mm}$.) has been reached, the sex-cells migrate laterally to their final positions on each side of the root of the mesentery. At the stage of $14 \mathrm{~mm}$., a large number of them degenerate, leaving only 60. A second generation of sex-cells soon begins to form from a source entirely different from the first, namely, from a transformation of ordinary peritoneal cells. Dustin is, in this regard, quite in accord with Bouin who expressed similar views regarding Rana. Dustin considers somewhat more briefly the corresponding stages in Rana and Bufo. Here he finds what he considers to be a substantially similar source of origin of the sexcells, namely the medial borders of the lateral plates of mesoderm. An incredible feature of his account is the statement that the lateral sex-gland anlagen contain no sex-cell at all comparable in size to those of the yolk-filled entoderm, at the period immediately prior to their union in the median line. Dustin would have us believe, nevertheless, that these selfsame sex-cells show a close resemblance to the entoderm cells immediately after this union of the lateral anlagen, and this in spite of the fact that both of these stages of development are so close together that the embryos upon which he made these observations were all of the same length. His own statement is as follows:

"Au moment où les ébauches paires séparées par une sorte de clivage des lames latérales du mésoblaste se sont rapprochées de la ligne médiane, les cellules sexuelles futures passent par une série de transformations cytologiques à la suite desquelles elles auront presque les caractères des cellules de l'hypoblaste vitellin. Les dimensions des corps cellulaires augmentent dans de fortes proportions; les grains vitellins deviennent beaucoup plus nombreux et plus volumineux; ils se colorent mieux par l'orange G. Par le fait de l'augmentation du nombre des plaquettes 
vitellines, le noyau, souvent réfoulé à la périphérie de la cellule, présente à sa surface une série d'encoches lui donnant un aspect hérissé (p. 476).

He finds the number of sex-cells in Rana to increase gradually, from 75 in the $8 \mathrm{~mm}$. stage to 90 in the $15 \mathrm{~mm}$. stage, at which time sex-cells begin to be formed by the transformation of ordinary peritoneal cells. Simultaneously there is a degeneration of sex-cells which is overbalanced by this process of transformation.

In criticism of the above views I wish, first of all, to admit the possibility that Dustin may be perfectly correct in his account of the origin of the first line of sex-cells from the lateral plates of mesoderm in Triton. His account of this feature is circumstantial and rather convincing. His account of a transformation of peritoneal cells into sex-cells during later stages is by no means so easy of acceptation. His figures to demonstrate this are not convincing.

His counts of sex-cells are not given in any circumstantial detail and there is no indication as to whether the number of sexcells recorded for any given stage is the result of a count of the sex-cells in one specimen or in several. One can not be blamed for be.ng skeptical of the value of such counts if made upon but one specimen of each stage, when so few stages are chosen to demonstrate general processes of degeneration and new formation. Such a process can only be established by a count of the sexcells of numerous specimens.

I wish to express my complete disbelief in the first appearance of the sex-cells in the lateral plates of mesoderm of Rana and Bufo in the manner described by Dustin. In my paper upon "An Important Period in the History of the Sex-Cells of Rana pipiens" ('07) I showed that the sex-cells migrate upward from the median dorsal portion of the gut entoderm at the time when the two lateral plates are pushing together to the median line in the process of forming the mesentery. Attention was called to the resemblance that this process bears to an actual pinching off of the mass of sex-cells by the inner margins of the plates of 
mesoderm. As pointed out in my article, the lateral plates of mesoderm, examined immediately before their approximation in the median line, show no cells which, as regards size or yolk content, in the least compare with the sex-cells.

It is especially gratifying to me to find support for my views in two recent papers. In one of these Kuschakewitsch ('08), referring to my paper of a few months before, stated: "Der Verfasser hat die Abschnüring von Dotterzellen längs der dorsalene Sagittallinie des Dottersackes im hinteren Teile des Rumpfes beobachtet und die Theilname dieser Dotterzellen am Aufbau einer kompakten Mesenterial-anlage festgestellt, die Bouin (1900)) als "ebauche génitale primordiale" aufgefasst hatte. Wie aus meiner Schilderung der entsprechenden Vorgänge in der Normalreihe von Rana esculenta zu ersehen ist, kann ich die Angaben von Allen vollständig bestätigen."

Another paper, appearing the same year (King, '08), gives an account of the origin of the sex-cells in Bufo lentiginosus which is in complete accord with the above, and states: "Allen's recent account of the origin of the sex-cells in Rana pipiens agrees essentially with what I have found in Bufo." Miss King finds no evidence in the course of development of any transformation of peritoneal cells into sex-cells as asserted by several writers among whom may be mentioned Bouin and Dustin. This is quite in accord with my observations upon Chrysemys ('06) in which the sex-cells were traced to the period of sexual maturity without finding any evidence of such transformation.

Miss May Jarvis ('08) in a paper upon "The Segregation of the Germ-Cells of Phrynosoma cornutum" (preliminary note) finds the sex-cells to take their origin in the entoderm of the vascular area on all sides of the embryo, even cranial to it, and notes a few in the region of the brain. Her results are in their main features confirmatory of my own work upon Chrysemys. The following quotation from her paper is self-explanatory: "Through the courtesy of Dr. Allen, I have been enabled to examine the more important stages in the migration of the germ-cells of Chrysemys; they are similar to my own material, as my conclu- 
sions, although differing from Dr. Allen's in details of early distribution and periods of migration, uphold his."

Rubaschkin ('08 and '09) in a couple of recent papers, has shown that the sex-cells of the rabbit and guinea-pig are first to be found in the entoderm at some distance on each side of the hind-gut and that they follow a path almost identical with that followed by the sex-cells of Chrysemys. These references to the coincidence of the views of other recent writers with my own are made to show that $I$ do not stand alone in placing emphasis upon the entodermal origin of the sex-cells in the vertebrates. At the same time I wish, however, to disclaim any intention of making at this time a sweeping claim that the sex-cells of all vetebrates arise in the entoderm. Wheeler's work on Petromyzon ('99) shows that they may be included in the mesoderm at the time when that layer is split off from the entoderm. He has, however, pointed out their similarity to the entoderm cells and their dissimilarity to the mesodermal cells among which they lie.

I do not seek to discredit the work of Dustin upon the sexcells of Triton; although his statements about the origin of the sex-cells in Rana and Bufo strike me as being very far from the mark, because they are so radically at variance with not only my own observations, but with those of King and Kuschakewitsch as well. Dustin, in his attitude toward the work of others, seems to consider that there must be a strict uniformity in all forms in both the place of origin and in the movements of the sexcells. He has apparently studied this problem first in Triton and at some length. His results, probably correct for that form, he has attempted to apply to Rana and Bufo as well, undeterred by the difficulties to which attention was called above. Dustin is quite ready flippantly to dismiss my work upon Chrysemys, because the results there expressed did not coincide with the views that he had formed regarding the origin of the sex-cells in Triton, Rana, and Bufo. ${ }^{1}$ The process of migration through the entoderm is so clear in Chrysemys, that it is unmistakable. The sex-cells are not only characterized by their larger size,

\footnotetext{
1 See postscript.
} 
definite, rounded outlines and fine chromatin network, but by their large yolk content and the fact that they do not divide during the stages in dispute.

The sex-cells are migratory to a high degree. The path and time of their migration may vary greatly within a given group of animals, as illustrated by the case of Amia and Lepidosteus. While in the forms that I have studied they are first to be observed in the entoderm, I am quite open to conviction that in other forms they may migrate from this layer into the potential mesoderm before the two layers are separated, as shown by Wheeler in Petromyzon. It is even conceivable that they may lie, from the very beginning of development, in material destined to form mesoderm-that they may never have existed among cells actually or potentially entodermal. The more recent development of our work along these lines, however, most certainly tends to show that it is usual among the vertebrates for the sex-cells to first appear in the entoderm.

\section{SUNMARY AND CONCLUSIONS}

1. The sex-cells of both Amia and Lepidosteus have their origin in the entoderm. In Amia they are first distinguishable in the peripheral entoderm from the lateral angle of the subgerminal cavity to the anlage of the blood cells.

In Lepidosteus they are first seen in the ventral and lateral portions of the gut-entoderm, although analogy with Chrysemys leads us to assume that they may have migrated through the entoderm to these regions from more lateral anlagen, similar to those from which the sex-cells of Amia arise. In both forms, the sex-cells arise only in the region of the hind-gut. None were found at any considerable distance in front of it.

2. The path of sex-cell migration in Amia carries them out of the peripheral entoderm directly into the overlying lateral plates of mesoderm, along which they travel, to come to rest near the medial edges of the latter. These portions are destined to join above the intestine to form the mesentery. As the splanchnic and somatic layers of the lateral plates of mesoderm 
split to form the coelome, the sex-cells adhere to the somatic layer. at a point near the root of the developing mesentery-the sex-gland anlage. They later sink into the peritoneum of this region, which afterwards proliferates to form a long ridge- the sex-gland. Very few sex-cells fall by the wayside in this migration, practically all reaching the sex-glands.

3. In Lepidosteus the sex-cells, first seen in the ventral and lateral portions of the gut-entoderm, migrate to occupy a position in the dorsal portion of it, from which they pass dorsally into the loose mesenchyme that forms the substance of the developing mesentery. As the mesentery becomes more narrow and compact, owing to the increase in size of the body cavity, the sexcells migrate to its dorsal portion and laterally to the sex-gland anlagen. Roughly speaking, one-half of the total number of sex-cells reach the sex-gland anlagen, the remainder being distributed between the intestinal entoderm, the mesodermal layers of the intestine, the mesentery and the tissues at and dorsal to the root of the intestine.

4. The number of the sex-cells in Amia and Lepidosteus is a matter of individual variation for those periods of development during which they do not undergo division. The average number in Amia, after the period when the migration from the entoderm to the mesoderm has been completed, up to the latest stage in which counts were made, was found to be 75 . In Lepidosteus it was 765 , an average of 636 of these occurring in the mesoderm.

5. There is a close resemblance between the nuclei of the sexcells and of the yolk cells. This is especially true of certain cells of the peripheral entoderm, although these grade by gradual transition forms into the large nuclei of the vitelline entoderm. This is probably due to the fact that both types of cells have undergone but little differentiation in the course of development.

\section{POSTSCRIPT}

A few days before proof of this article came to hand, I received, through the courtesy of the author, a reprint of an article by A. P. Dustin, entitled, "L'Origine et l'Evolution des Gonocytes chez 
les Reptiles," (Archives, de Biologie, 1910). This article deals with the origin of the sex-cells in Chrysemys marginata, the form which served as a subject for my own work of 1906 . As noted above, Dustin in his paper "Recherches sur l'origine des gonocytes chez les Amphibiens" 1907, exhibited scant respect for my work on the sex-cells of Chrysemys. It was, no doubt, in large part, this feeling that prompted him to repeat my work. While he, no doubt, expected to find in this form a confirmation of his previously expressed views, he is led to substantiate completely my statements regarding the entodermal origin of the sex-cells. He traces them along the same migration path that I demonstrated four years before. For all this he now gives me full credit and support; but takes issue with my statements regarding the distribution of the sex-cells prior to their migration into the embryo, and, furthermore, claims to have evidence to show that there is a new formation of sex-cells, due to a transformation of ordinary peritoneal cells. These points of controversy and certain other minor ones can not be considered here, but I promise a full discussion of them in another place. I may say that I am fully prepared to maintain my views upon all of the points at issue.

On my part, the work that I have carried on upon Necturus since this paper was written, has given me results quite similar to those at which Dustin arrived in his work upon Triton. I may say that preliminary studies have convinced me that the sex-cells arise in an essentially similar manner in Amblystoma. We then see that, in all three of these urodeles, the sex-cells arise from the inner edges of the lateral plates of mesoderm. I owe it to myself to call attention to the fact that I have at no time disputed the accuracy of Dustin's work upon Triton. While the evidence secms to me quite clear that this is the usual, if not the universal, mode of origin of the sex-cells among the urodele ampinibians, I am ready to maintain with equal vigor the entodermal origin of the sex-cells in the aruran amphibians, at the same time admitting the possibility that exceptions to this apparent rule may be discovered. I do not feel however, that Dustin has proved his case in Rana fusca and Bufo vul- 
garis. The discussion of his work above gives the reasons for my position in this matter.

Not only does it seem probable that the sex-cells arise during early stages in the mesoderm of the urodeles, but this seems to be the case in the teleosts as well. The most recent and satisfactory support of this view is contained in the excellent paper of Dr. Gideon S. Dodds upon the "Segregation of the Germ-Cells of the Teleost, Lophius," in the Journal of Morphology, 1910. Here again, we must urge caution in forming a sweeping generalization from the facts thus far at hand. There is certainly a wide field for work in the study of the origin of the sex-cells of the vertebrates. It is a subject which should be approached in a spirit of broad toleration for the views of others. The sexcells are cells that retain their early embryonic character after the somatic cells have undergone specialization. It seems, from a number of observations made by different authors, that in most forms the sex-cells first make their appearance in the entoderm-the germ layer whose cells appear to maintain their primitive embryonic characters longer than do those of the other germ layers. At the same time, unimpeachable evidence shows that this apparently logical process is not universal, and I have at no time claimed that it is. The sex-cells, as shown by Nussbaum, Eigenmann, Beard and others, do not belong to any one germ layer, but are, in a sense at least, independent of the somatic tissues. They are free to follow their own path in their travels from the place of origin to the sex-gland anlagen, where they finally come to rest. While this path is no doubt identical or similar in closely allied species and in more general divisions of the vertebrates, I do not feel that we are justified in attributing a high degree of phylogenetic importance to the different steps in the migration paths through which they travel.

I wish to express my indebtedness for the work of our departmental artists, Misses Hedge and Battey. I am indebted to Miss Hedge for the execution of diagrams 1-6 and for figs. 9, 10, 14, 15, 21, 22, 25 and 26; and to Miss Battey for figs. 11, 12, 13, 23, and 24. The remaining drawings are my own. 


\section{BIBLIOGRAPHY}

Allen, Bennet M. 1906 Origin of the sex-cells of Chrysemys. Anat. Anz. Bd. 29.

1907a A statistical study of the sex-cells of Chrysemys marginata, Anat. Anz. Bd. 30.

$1907 b$ An important period in the history of the sex cells of Rana pipiens. Anat. Anz., Bd. 31.

1909 The origin of the sex-cells of Amia and Lepidosteus. Anat. Rec., Vol. 3.

Dustris, A. P. 1907 Recherches sur l'origine des gonocytes chez les Amphibiens. Arch. de Biologie, tome 23.

J ARvis, MaY. 1908 The segregation of the sex-cells of Phrynosoma. Biol. Bul., Vol. 15.

King, Het.en Dean. 1908 The oogenesis of Bufo lentiginosus. Jour. Morph., Vol. 19.

KUSCHAKEwitSCH, S. 1908 Ueber den Ursprung der Urgeschlechtszellen bei Rana pipiens. Stzber. math. phys. Klasse, k. bayer. Akad. Wiss., Bd. 38.

Rubaschkin, W. 1907 Zur Frage von der Entstehung der Keimzellen bei Säugetierembryonen. Anat. Anz., Bd. 31.

1909 Ueber die Urgeschlechtszellen bei Säugetieren. Anat. Hefte, Bd. 39.

WHEELER, W. M. 1899 The development of the urogenital organs of the lamprey. Zool. Jahrbuch., Anat. Abth., Bd. 13. 


\section{ABBREVIATIONS FOR ALL FIGURES}

Arch., Archenteron

Coel., Coelomic cavity

Ect., Ectoderm

Gut End., Gut entoderm

Int., Intestine

Lat. Mes., Lateral plate of mesoderm Mes., Mesentery

Meson., Mesonephros

Myo., Myotome

Noto., Notochord

$P$. Card., Post cardinal vein
Periph. End., Peripheral entoderm Roof End., Roof cntoderm

$S$. C., Sex-cells

S. Gl., Sex-gland

Sub-Germ. Cav., Sub-germinal cavity

Sub-ferm. End., Sub-germinal entoderm

$S w . B l$, Swim bladder.

Vit. End., Vitelline entoderm

Wolff. D., \}olffian duel

W. D. 


\section{PLATE 1}

\section{EXPLANATION OF FIGURES}

1 Diagram to show the migration path of the sex-cells in Chrysemys marginata.

2 Diagram to show the migration path of the sex-cells in Rana pipiens.

\section{PLATE 2}

\section{EXPLANATION OF FIGURES}

3 Diagram to show the migration path of the sex-cells in Lepidosteus osseus.

4 Diagram to show the last phase of the migration of the sex-cells in Lepidosteus osseus.

5 Diagram to show the migration path of the sex-cells of Amia calva.

6 Diagram to show the last phase of the migration of the sex-cells in Amia calva.

JOURNAL OF MORPHOLOGT, VOL. 22, NO. 1 


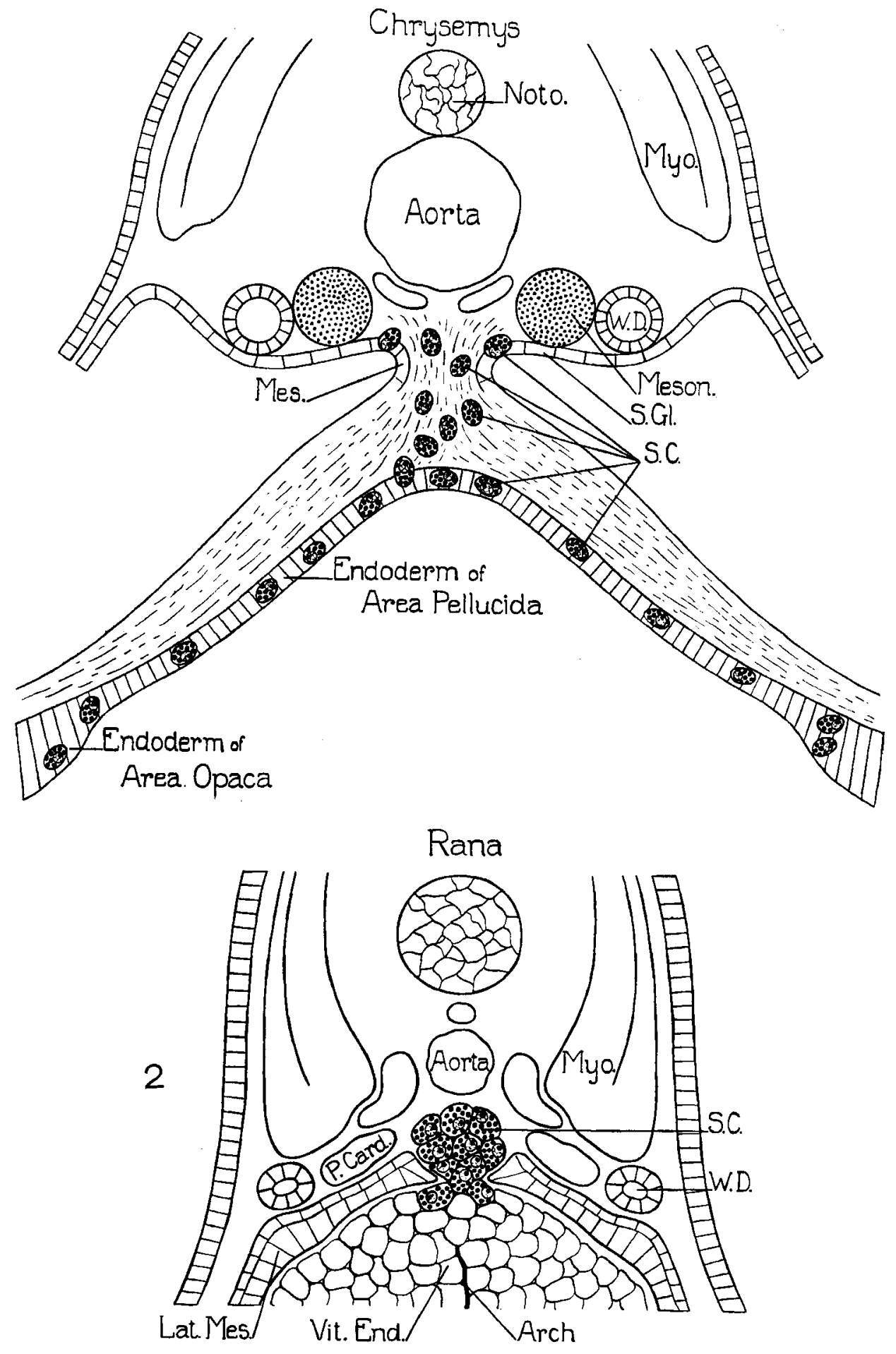

JOURAAL OF MORPHOLOGT, VOL. 22, NO. 1 


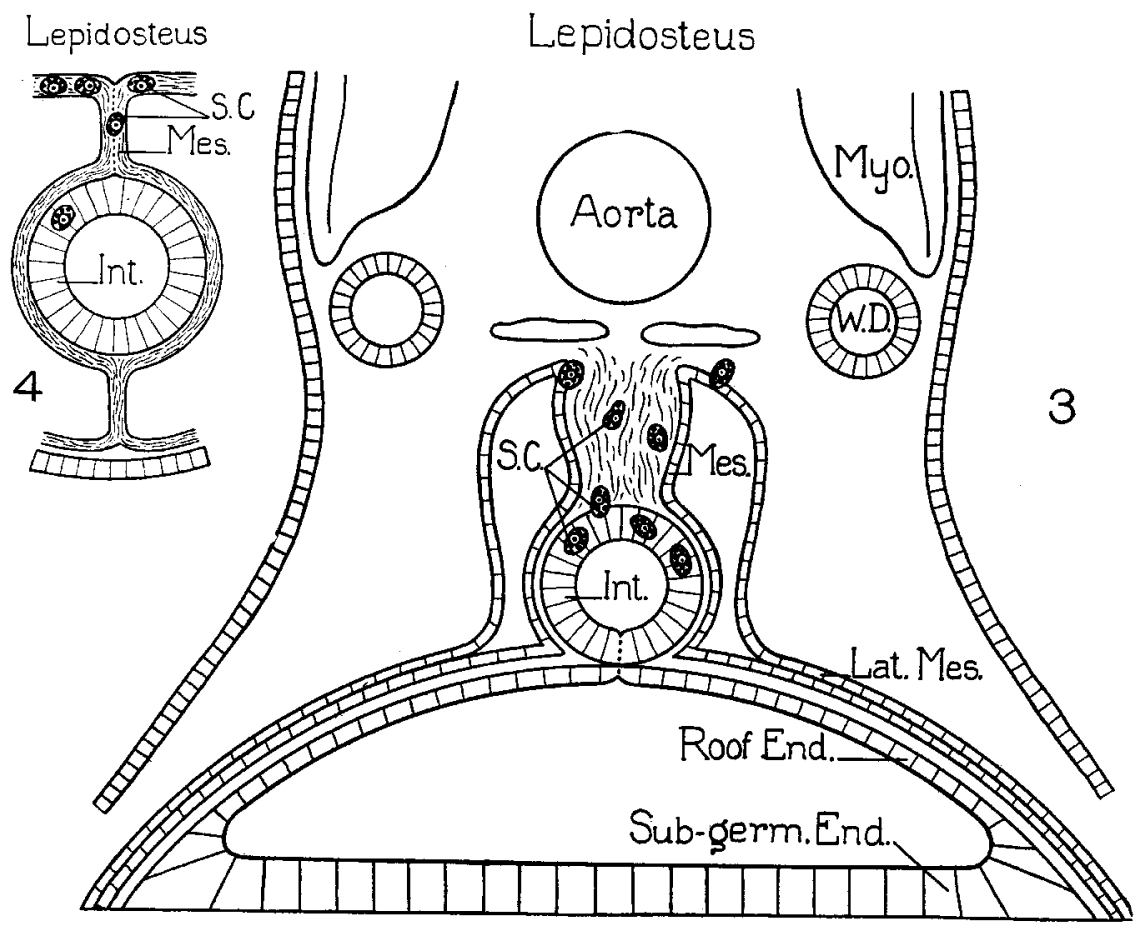

\section{Arnia}

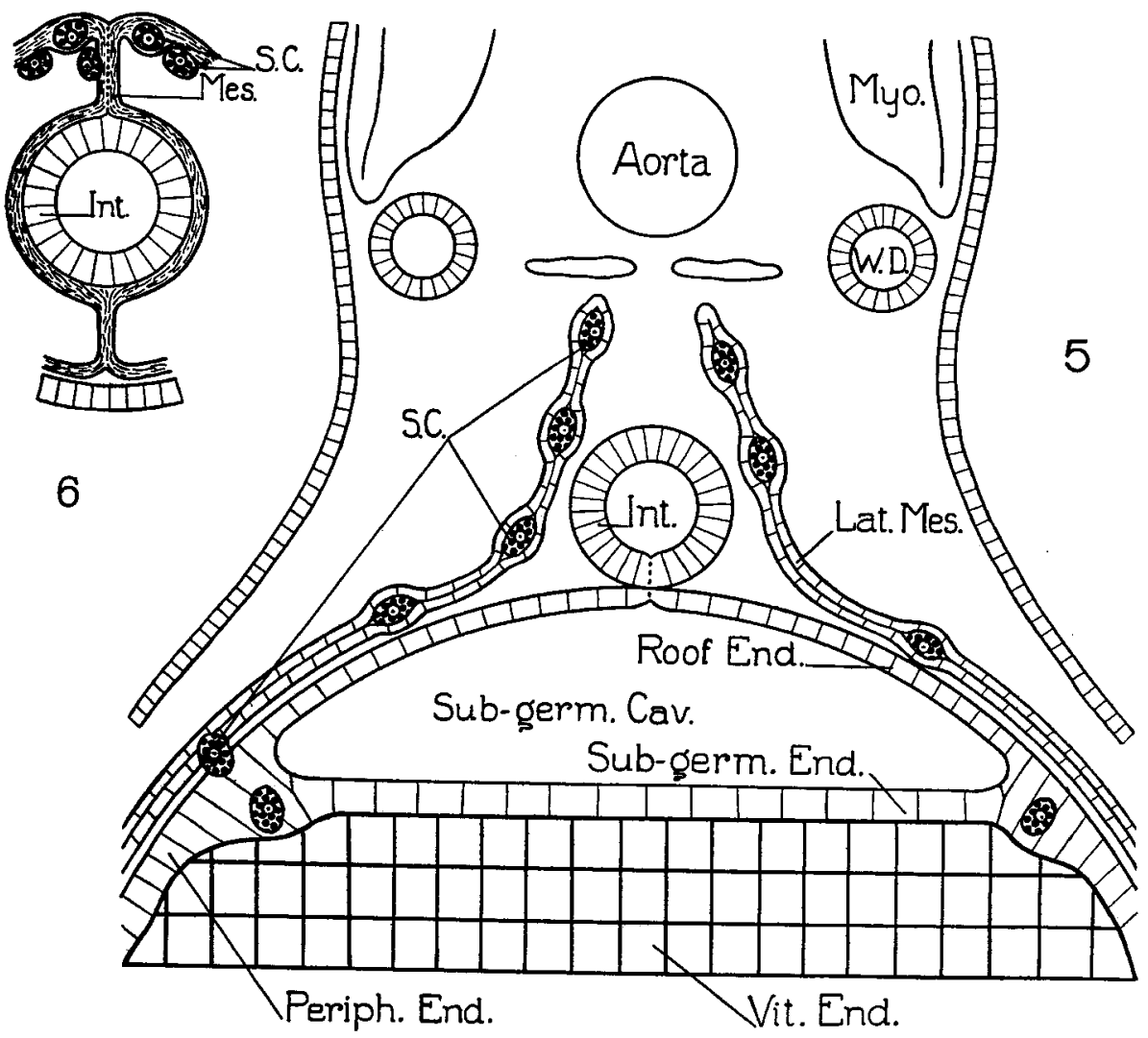




\section{PLATE 3}

\section{EXPLANATION OF FIGURES}

7 Transverse section through the hind-gut of an $8.6 \mathrm{~mm}$. larva of Lepidosteus osseus. $\times 300$.

8 Transverse section through the hind-gut of a $9.3 \mathrm{~mm}$. larva of Lepidost.eus osseus. $\times 300$.

9 Transverse section through the hind-gut of a $10.7 \mathrm{~mm}$. larva of Lepidosteus osseus. $\times 300$.

10 Transverse section through the hind-gut of a $14.1 \mathrm{~mm}$. larva of Lepidosteus osseus. $\times 300$.

11 Transverse section through the hind-gut of a $17 \mathrm{~mm}$. larva of Lepidosteus osseus. $\times 300$. 


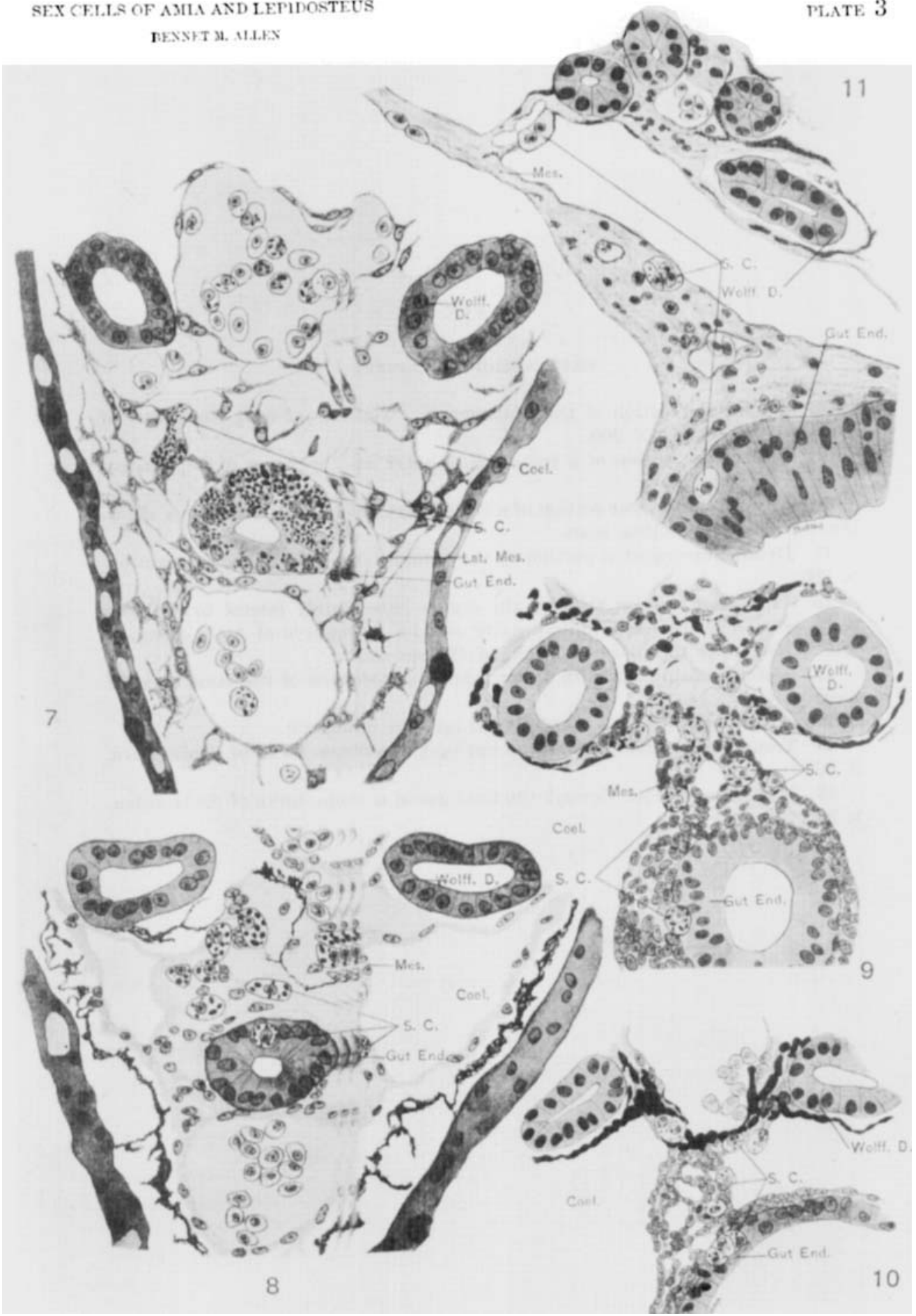




\section{PLATE 4}

\section{EXPLANATION OF FIGURFS}

12 Transverse section of the rudimentary sex-glands of a $24 \mathrm{~mm}$. larva of Lepidosteus osseus. $\times 300$.

13 'Transverse section of a sex-gland of a $110 \mathrm{~mm}$. specimen of Lepidosteus osseus. $\times 300$.

14 Part of a transverse section of a $17 \mathrm{~mm}$. larva of Lepidosteus osseus, showing the reduced vitelline mass.

15 Detail drawing of a portion of the vitelline mass of the above section. $\times 300$.

16 Transverse section through the region immediately lateral to the posterior portion of the sub-germinal cavity of a $147 \mathrm{hr}$. embryo of Amia calva. $X$ 300. This shows the place of origin of the sex-cells.

17 Section passing similarly through another specimen of the same stage of Amia calva. $\times 300$.

One sex-cell shown as it is pushing up into the mesoderm.

18 Transverse section through the hind-gut of a $6 \mathrm{~mm}$. larva of Amia calva. $\times 300$.

19 Transverse section through the hind-gut of a $7 \mathrm{~mm}$. larva of Amia calva. $\times 300$. 


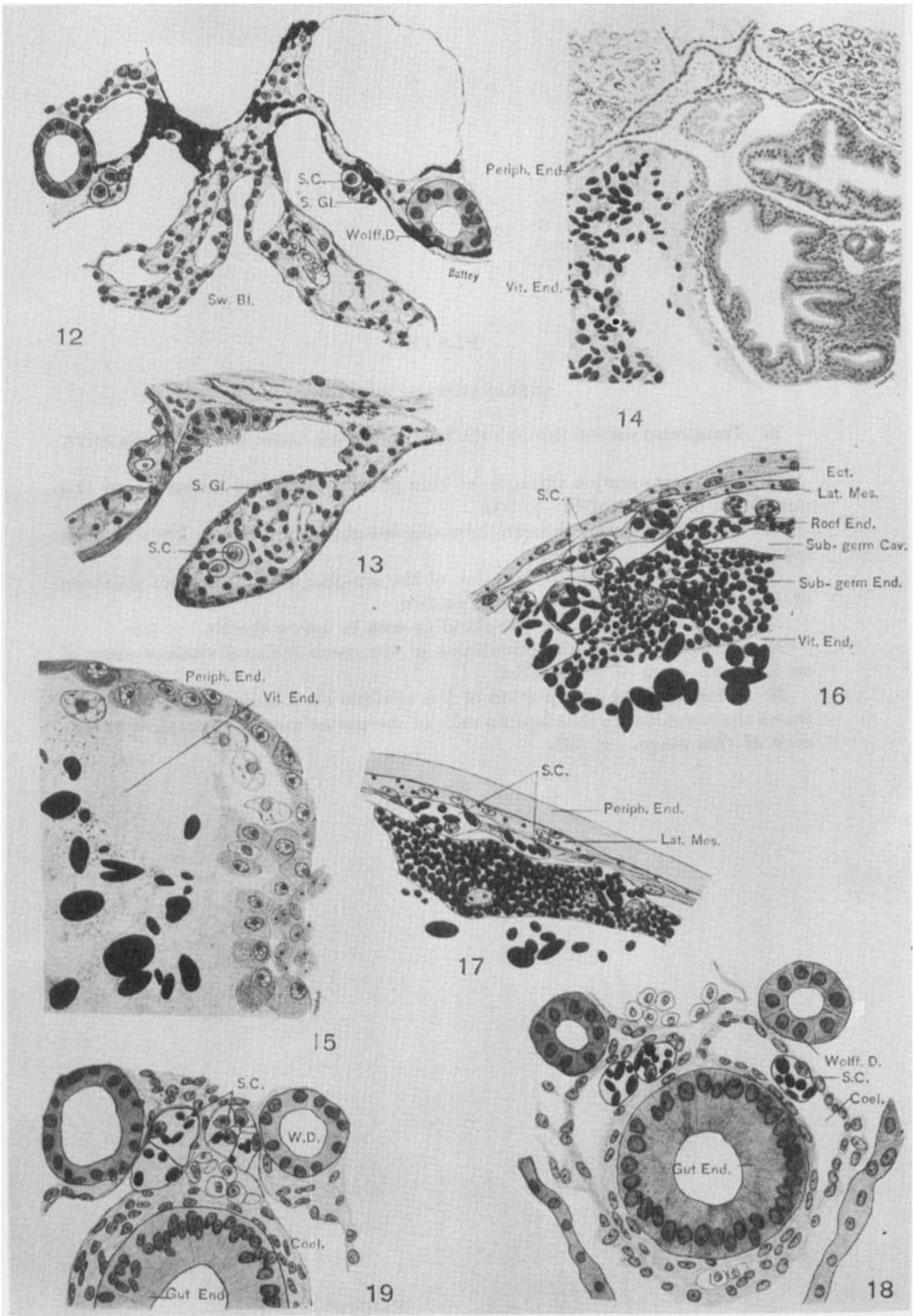




\section{PLATE 5}

\section{EXPLANATION OF FIGURES}

20 Transverse section through the hind-gut of a $9.1 \mathrm{~mm}$. larva of Amia calva. $\times 300$.

21 Transverse section through the hind-gut and sex-gland anlage of an 11.4 mm. larva of Amia calva. $\times 300$.

22 Transverse section through the young sex-glands of a $16 \mathrm{~mm}$. larva of Amia calva. $\times 300$.

23 Sketch to show the orientation of the sex-glands in a $40 \mathrm{~mm}$. specimen of Amia calva as seen in transverse section.

24 Detail drawing of the sex-gland as seen in above sketch. $\times 300$.

25 Drawing to show the orientation of the much reduced vitelline mass of an $11.4 \mathrm{~mm}$. larva of Amia calva.

26 Detail drawing of a portion of the vitelline mass indicated above. This shows the resemblance that certain cells of the peripheral entoderm show to sexcells of this stage. $\times 300$. 


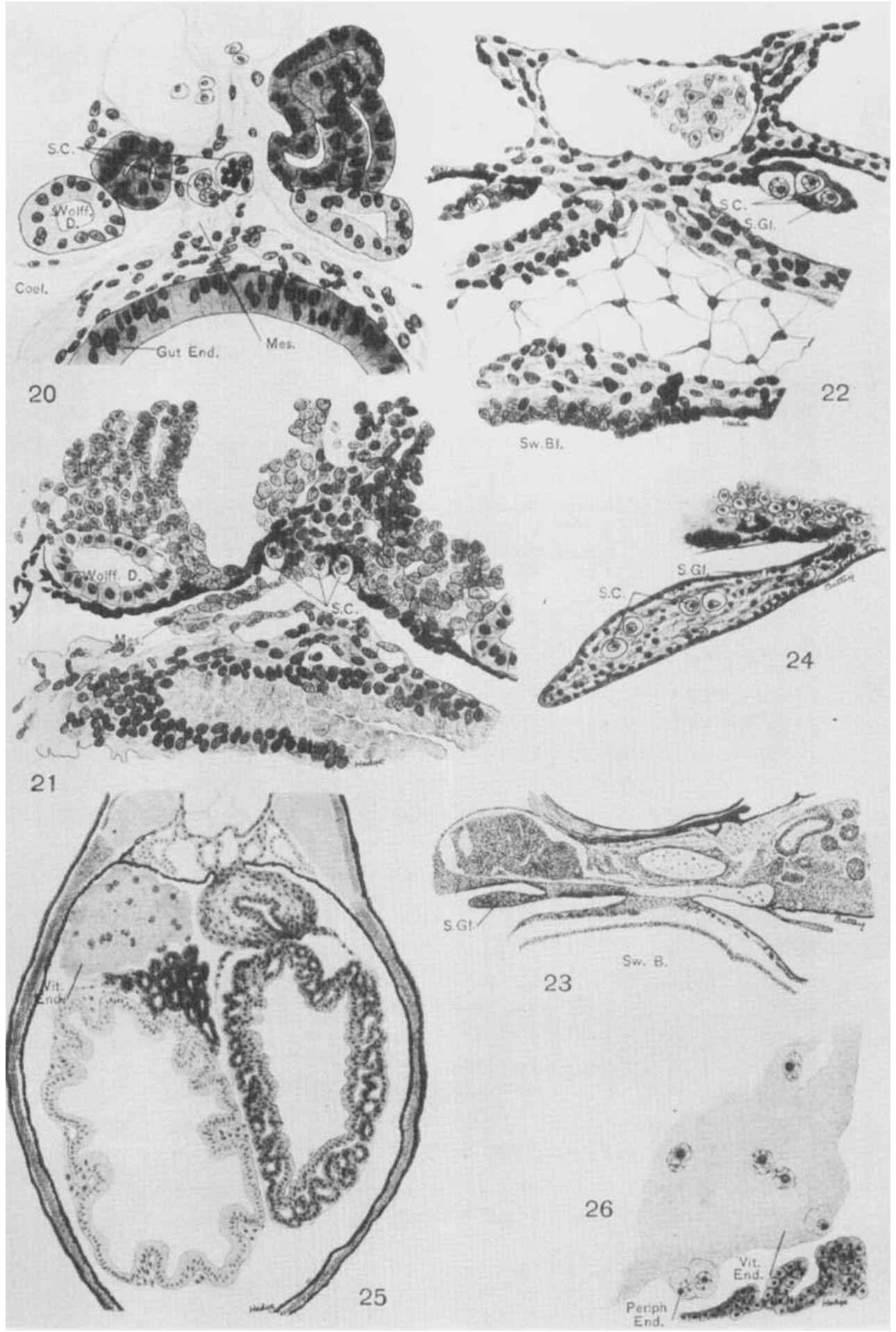

